\title{
Evaluation of Water Use Efficiency of Rice Genotypes under Different Rice Establishment Methods and Different Growing Environment
}

\author{
Kamlesh Kumar Sahu ${ }^{1 *}$, S. Pasupalak ${ }^{1}$ and Uttam Kumar Diwan ${ }^{2}$ \\ ${ }^{1}$ Department of Agrometerology, OUAT, Bhubaneswar (Odisha), India \\ ${ }^{2}$ Department of Agrometeorology, IGKV, Raipur (CG), India \\ *Corresponding author
}

\begin{abstract}
A B S T R A C T
Keywords

Water use

efficiency, Rice,

Pooja, Naveen

Article Info

Accepted:

20 December 2017

Available Online:

10 January 2018

The present investigation was carried out during kharif season 2015 at research farm of College of Agriculture, Orissa University of Agriculture and Technology, Bhubaneswar, it was laid out in a Split-Split plot design replicated thrice with three establishment methods (M1-Direct Seeding, M2-Unpuddled transplanting, and M3Puddled transplanting) as main plot treatment, two dates of sowing (D1-27th June and D2-11th July) as sub plots and two varieties (V1-Naveen and V2-Pooja) as Sub-Sub plot treatments. The minimum water use efficiency was noticed in rice cultivar 'under early puddle transplanted situation as compared to the other treatment combinations. Whereas, the lowest water use efficiency was observed in cv. 'Naveen' under late sown direct seeded condition. The transplanted rice registered maximum grain yield $(3483 \mathrm{~kg} / \mathrm{ha})$ as compared to unpuddled transplanted rice and direct seeded rice.
\end{abstract}

\section{Introduction}

Rice is the staple food of over half the world's population, and a vital nutritional source for rural poor of most of the countries in the world providing $20 \%$ of their dietary energy. The demand of rice as staple food for about 3 billion people is expected to increase further with increase in population. Globally rice is grown in 162.3 mha, and India accounts for $27.47 \%$ with a cultivated area of $44.6 \mathrm{mha}$, the corresponding production being 738.1 and $104.20 \mathrm{mt}$. The average production under Indian condition is $2.44 \mathrm{t} \mathrm{ha}^{-1}$ compared to the world's average of $4.5 \mathrm{t} \mathrm{ha}^{-1}$ (CACP2015).
Odisha occupies an area of $4.41 \mathrm{~m}$ ha producing $6.94 \mathrm{mt}$ with an average productivity of $1.57 \mathrm{t} \mathrm{ha}^{-1}, 35.56 \%$ less than the national average (Govt. of Odisha, 201213).

With its ability to adopt itself to a wide range of geo-hydrological situations, rice enjoys a unique place among the field crops. Based on two major environmental determinates of source like water and degree of flooding, rice can be grouped under different ecosystem such as rainfed upland, rainfed low-land, medium land, deep water and tidal wetlands. In spite of its wider adaptability and 
cultivation, are we in a position to balance rice production under these ecosystems. Besides maintaining a healthy soil environment is a major point of concern of all the stakeholders,

Transplanting in puddle soil is the most dominant and traditional method of establishment in irrigated low land rice. Puddling, the typical pre planting management practice, is done to reduce water infiltration and to maintain the standing water in the field, which helps in weed management and facilitates easier transplanting (Sharma and De data, 1986) The depth of the water influences the type and density of weed flora (Kent and Jonson, 2001, Kumar and Ladha, 2011).

Besides water management, tillage can also influence weed emergence due to changes in the mechanical characteristics(bulk density, penetration resistance, aggregate mean weight diameter and surface roughness) of the seedbed (Carman, 1996) as well as the vertical distribution of seeds in soil (Chauhan and Johnson, 2009). Puddled flooded Soil has many other benefits such as neutralising soil $\mathrm{pH}$, improving the availability of plant nutrients ( $\mathrm{P}, \mathrm{K}, \mathrm{Ca}, \mathrm{Mg}, \mathrm{Mn}$ and $\mathrm{Fe}$ ) and allowing for the accumulation of organic matter (Poonamperuma, 1972; Sahrawat, 2005).

Mainly the indirect increase in the availability of nutrient by puddling is through the reduction of cation leaching (Aggarwal et al., 1995). In spite of all such advantages, puddling in rice associated with many problem of the soil structure, creation of hard Pan, increased methane emission, increased bulk density and soil compaction (Kirchhof et al., 2000). Moreover puddling and transplanting also requires large amount of scarce water resources as well as labour (Kumar and Ladha, 2011). The puddling rice transplanting operations consumes about $25 \%$ of the total water required for rice during the growing season. The destruction of soil structure and formation of hard pan during puddling may have adverse effects on the growth and yield of subsequent non rice crop in the relation and these crops also require more energy for field preparation (Kumar and Ladha, 2011).

\section{Materials and Methods}

\section{Water use efficiency}

\section{Effective Rainfall (ER)}

Effective rainfall is the proportional of rainfall useful in crop production (DASTANE, 1972). The storage capacity of the soil and rooting depth of the crop are the important factors in deciding the magnitude of effective rainfall. Any rain received after the soil has attained field capacity (FC) down to the rooting zone becomes ineffective.

\section{Water use Efficiency (WUE)}

The field Water use efficiency was calculated by using the following formula.

\section{FWUE=Economic yield (kg ha- $\left.{ }^{1}\right) /$ Consumptive use of water $(\mathrm{cm})$ \\ Water Requirement (WR)}

It was estimated by the following formula

$\mathrm{WR}=\mathrm{ER}+\mathrm{IR}+\Delta \mathrm{SW}+\Delta \mathrm{GW}$

Where:

$\mathrm{ER}=$ effective rainfall $(\mathrm{cm})$

$\mathrm{IR}=$ Gross irrigation requirement

$\Delta \mathrm{SW}=$ Soil water contribution $(\mathrm{cm})$

$\Delta \mathrm{GW}=$ Ground water contribution $(\mathrm{cm})]$

It has been presumed that the soil profile and ground water table contribution are very negligible during kharif season. 


\section{Statistical analysis}

The data collected for different characters were subjected to statistical Analysis and subsequent $F$ test appropriate to the experimental design (cochram and cox. 1950). The standard error of mean (SEm \pm and difference $(\mathrm{CD})$ at 5 percent and significance level was worked out for the different parameters.

\section{Results and Discussion}

\section{Grain yield}

The grain yield of rice is a function of total number of panicles, number of grains per panicle and the grain weight, which was significantly influenced by the planting methods, dates of sowing and the rice cultivars (Table 1). The transplanted puddled rice registered maximum grain yield of $3438 \mathrm{~kg} / \mathrm{ha}$ which was almost $17.5 \%$ more than unpuddled transplanted rice and $42.7 \%$ more than direct seeded rice $2440 \mathrm{~kg} / \mathrm{ha}$. The early sown crop $\left(27^{\text {th }}\right.$ June) produced maximum grain yield (3117kg/ha) with yield advantage of almost $19 \%$ than that crop sown on 11 July (2808 $\mathrm{kg} / \mathrm{ha}$ ). The highest grain yield was obtained with $c v$. Pooja $(3070 \mathrm{~kg} / \mathrm{ha})$ which was almost $7.5 \%$ higher than that observed with $c v$. Naveen $(2856 \mathrm{~kg} / \mathrm{ha})$. Interaction between varieties and dates of sowing was found nonsignificant.

\section{Straw yield kg/ha.}

Unlike grain yield the straw yield was also significantly influenced by the different rice establishment methods, planting dates and genotype. Table 1 . The maximum straw yield $(3445 \mathrm{~kg} / \mathrm{ha})$ was recorded from paddy crop transplanted after puddling which was almost $19 \%$ and $40 \%$ higher than that observed in unpuddled transplanted and direct seeded rice, respectively. Similarly the crop planted on $\left(27^{\text {th }}\right.$ June) registered more straw yield (2997 $\mathrm{kg} / \mathrm{ha}$ ) as compared to the crop planted on $11^{\text {th }}$ July. The rice $c v$. Pooja produce almost $11 \%$ higher straw yield than $c v$. Naveen $(2783 \mathrm{~kg} / \mathrm{ha})$. The interaction effects were nonsignificant.

Table.1 Grain yield, straw yield, and harvest index as affected by different establishment methods, growing environments and varieties

\begin{tabular}{|c|c|c|c|}
\hline Management & Grain yield kg/ha & Straw yield kg/ha & Harvest Index (\%) \\
\hline M1 & 2440 & 2458 & 49.81 \\
\hline M2 & 2964 & 2896 & 50.06 \\
\hline M3 & 3483 & 3445 & 50.27 \\
\hline SEm+ & 62.6 & 24.4 & 0.25 \\
\hline CD (0.05) & 197.4 & 77.0 & NS \\
\hline & Growing Environments \\
\hline D1 & 3117 & 2997 & 50.89 \\
\hline D2 & 2808 & 2868 & 49.47 \\
\hline SEm+ & 51.1 & 19.9 & 0.21 \\
\hline CD (0.05) & 161.1 & 62.9 & 0.66 \\
\hline & & Variety & \\
\hline V1 & 2856 & 2783 & 50.64 \\
\hline V2 & 3069 & 3081 & 49.90 \\
\hline SEm+ & 59.1 & 78.9 & 0.17 \\
\hline CD (0.05) & 182.2 & 243.2 & 0.53 \\
\hline
\end{tabular}


Table.2 Water use efficiency of two cultivars of rice as influenced by different establishment methods and dates of sowing

\begin{tabular}{|l|c|c|c|c|c|}
\hline Treatment & Grain (kg/ha) & $\begin{array}{c}\text { Rainfall } \\
(\mathbf{m m})\end{array}$ & $\begin{array}{c}\text { Irrigation } \\
(\mathbf{m} \mathbf{m})\end{array}$ & $\begin{array}{c}\text { Total water } \\
(\mathbf{m m})\end{array}$ & $\begin{array}{c}\text { WUE } \\
\text { (kg/ha.mm) }\end{array}$ \\
\hline M1D1V1 & 2412.3 & 748.3 & 180 & 928.3 & 25.99 \\
\hline M1D1V2 & 2664.6 & 751.3 & 180 & 931.3 & 28.61 \\
\hline M1D2V1 & 2193.0 & 731.8 & 180 & 911.8 & 24.05 \\
\hline M1D2V2 & 2493.4 & 733.6 & 180 & 913.6 & 27.29 \\
\hline M2D1V1 & 3070.2 & 748.3 & 240 & 988.3 & 31.07 \\
\hline M2D1V2 & 3004.4 & 751.3 & 240 & 991.3 & 30.31 \\
\hline M2D2V1 & 2815.8 & 731.8 & 240 & 971.8 & 28.97 \\
\hline M2D2V2 & 2969.3 & 733.6 & 240 & 973.6 & 30.50 \\
\hline M3D1V1 & 3530.9 & 748.3 & 300 & 1048.3 & 33.68 \\
\hline M3D1V2 & 4019.7 & 757.3 & 300 & 1057.3 & 38.02 \\
\hline M3D2V1 & 3114.0 & 731.8 & 300 & 1031.8 & 30.18 \\
\hline M3D2V2 & 3267.5 & 733.6 & 300 & 1033.6 & 31.61 \\
\hline
\end{tabular}

\section{Harvest index (\%)}

The estimated value of harvest index influenced significantly by the dates of sowing and rice genotypes but was nonsignificant with different planting methods, thus the harvest index values of the crops harvested under different planting methods were at par. The maximum harvest index value $(50.89 \%)$ observed in early sown crop followed by the crop sown $11^{\text {th }}$ July $(49.47 \%)$ but among the tested rice genotype $c v$. Naveen registered higher harvest index value $(50.64 \%)$ as compared to $c v$. Pooja (49.90\%).

\section{Water use efficiency (WUE)}

The rainfall received and irrigation applied to both the rice genotypes under different rice establishment methods and dates of sowing are depicted in Table 2. The water use efficiency of both the cultivars under different treatment combinations estimated and presented in Table 2 . The data clearly revealed that the minimum water use efficiency was noticed in rice cultivar Pooja under early puddled transplanted situation
$\left(\mathrm{M}_{3}-\mathrm{D}_{1} \mathrm{~V}_{2}-38.02 \mathrm{Kg} / \mathrm{ha} . \mathrm{mm}\right)$ as compared to other treatment combinations. Whereas, the lowest water use efficiency was observed in $\mathrm{cv}$. Naveen under late sown direct seeded condition $\left(\mathrm{M}_{1}-\mathrm{D}_{2} \mathrm{~V}_{2}-24.05 \mathrm{~kg} / \mathrm{ha} . \mathrm{mm}\right)$.

\section{References}

Aggarwal, G.C, Sidhu, S, Sekhon, N.K., Saadhu, S.K, Sor, H.S. 1995. Puddling and $\mathrm{n}$ management effect crop response in a rice -wheat cropping system. Soil and Tillage Research. 39:129-139.

Carman, K. 1996. Effect of different tillage systems on soil properties and wheat yield in middle Anatolia. Soil and Tillage Research, 40:204-207.

Chauhan, B.S and Johnson, D.E. 2009. Influence of tillage system on weed seedling emergence pattern in rainfed rice. Soil and Tillage Research. 106:1521.

Kent, R.J and Johnson, D.E. 2001. Influence of flood depth and duration on biology and growth of low land rice weed, Coledivoire, crop prof. 20:691-694

Kirchhof G., Priyono, S., Utomo, W.H., 
Adisarwanlo, T., Daccaay, E.V. and So, H.B. 2000. The effect of soil puddling on the soil physical properties and the growth of rice and post rice crops. Soil and Tillage Research. 56:37-50.

Kumar, V and Ladha, J.K. 2011. Direct seeding of rice; recent development and future research needs. Advances in Agronomy. 111:297-413.

Sharma, P.K. and De dutta, S.K. 1986. Physical properties and processes of puddled rice soil. Advances in soil science. 5:139-153.

\section{How to cite this article:}

Kamlesh Kumar Sahu, S. Pasupalak and Uttam Kumar Diwan. 2018. Evaluation of Water Use Efficiency of Rice Genotypes under Different Rice Establishment Methods and Different Growing Environment. Int.J.Curr.Microbiol.App.Sci. 7(01): 2534-2538.

doi: https://doi.org/10.20546/ijcmas.2018.701.304 